\title{
Clostridium tagluense sp. nov., a psychrotolerant, anaerobic, spore-forming bacterium from permafrost
}

\author{
Stanislav V. Suetin, ${ }^{1}$ Viktoria A. Shcherbakova, ${ }^{1}$ Natalya A. Chuvilskaya, ${ }^{1}$ \\ Elisaveta M. Rivkina, ${ }^{2}$ Natalya E. Suzina, ${ }^{1}$ Anatoliy M. Lysenko ${ }^{3}$ \\ and David A. Gilichinsky²
}

Correspondence

Stanislav V. Suetin suetin@ibpm.pushchino.ru

\author{
${ }^{1}$ Skryabin Institute of Biochemistry and Physiology of Microorganisms, Russian Academy of \\ Sciences, Pushchino 142290, Moscow Region, Russian Federation \\ ${ }^{2}$ Institute of Physicochemical and Biological Problems in Soil Science, Russian Academy of \\ Sciences, Pushchino 142290, Moscow Region, Russian Federation \\ ${ }^{3}$ Winogradsky Institute of Microbiology, Russian Academy of Sciences, 7/2 Prospekt 60-let \\ Oktyabrya, Moscow 117811, Russian Federation
}

The genus Clostridium, one of the largest genera of the prokaryotes, currently includes more than 170 species of anaerobic, spore-forming, Gram-positive bacteria that are unable to carry out dissimilatory reduction of sulfate. More than 70 species fall within cluster I, now regarded as the genus Clostridium sensu stricto, as defined on the basis of 16S rRNA gene sequence similarity (Hippe et al., 1992; Collins et al., 1994; Garrity et al., 2004, Wiegel et al., 2006). Although most of the species included in cluster I have been isolated from temperate environments, a series of psychrophilic and psychrotolerant species have been also described: Clostridium estertheticum subsp. estertheticum (Collins et al., 1992; Spring et al., 2003), C. estertheticum

The GenBank/EMBL/DDBJ accession number for the 16S rRNA gene sequence of strain $A 121^{\top}$ is DQ296031.

Plots showing the effects of temperature and $\mathrm{NaCl}$ concentration on growth of strain $\mathrm{A} 121^{\top}$, a comparison of the fatty acid profiles of strain $\mathrm{A} 121^{\top}$ and related type strains and an extended 16S rRNA gene sequence-based neighbour-joining tree are available as supplementary material with the online version of this paper. subsp. laramiense (Kalchayanand et al., 1993; Spring et al., 2003), Clostridium algidicarnis (Lawson et al., 1994) and Clostridium frigidicarnis (Broda et al., 1999) from vacuumpacked meat, Clostridium vincentii from low-salinity pond sediments of the MacMurdo ice shelf in Antarctica (Mountfort et al., 1997), four species isolated from an Antarctic microbial mat (Clostridium frigoris, C. lacusfryxellense, C. bowmanii and C. psychrophilum) (Spring et al., 2003) and 'Clostridium algoriphilum', isolated from a water brine in Siberian permafrost (Shcherbakova et al., 2005). Phylogenetic data from previous studies (Spring et al., 2003; Shcherbakova et al., 2005; Gilichinsky et al., 2005) showed that all of these species, with the exception of $C$. algidicarnis, C. frigidicarnis and C. vincentii, form an isolated branch within cluster I of the genus Clostridium. In this study, we describe a novel psychrotolerant bacterium of the genus Clostridium (strain $\mathrm{A} 121^{\mathrm{T}}$ ) that was isolated from a permafrost core in the Canadian High Arctic. Based on phylogenetic analysis of its $16 \mathrm{~S}$ rRNA gene sequence, DNA-DNA hybridization data and phenotypic character- 
istics, this isolate is shown to be closely related to the above-mentioned psychrotolerant and psychrophilic Clostridium species.

The isolation source (Quaternary-aged permafrost with present-day temperature of $-6{ }^{\circ} \mathrm{C}$ ) was sampled from the upper horizon $(18 \mathrm{~m})$ of the core of the deep $(451 \mathrm{~m})$ borehole 92GSCTaglu in a gas-hydrate field located in the Mackenzie Delta, Northwest Territories, Canada $\left(69^{\circ} 22^{\prime} \mathrm{N}\right.$ $\left.135^{\circ} 00^{\prime} \mathrm{W}\right)$. The recovered sample of ice-bonded sand of lake origin was kept frozen until laboratory analysis. Anaerobic strain $\mathrm{A} 121^{\mathrm{T}}$ was isolated from the sample and maintained using Hungate anaerobic techniques (Hungate, 1969). Both enrichment and pure cultures were grown in $15 \mathrm{ml}$ Hungate roll tubes with $10 \mathrm{ml}$ medium and $100 \%$ $\mathrm{N}_{2}$ atmosphere. An enrichment culture was obtained using a medium of the following composition $\left(\mathrm{g} \mathrm{l}^{-1}\right)$ : $\mathrm{KH}_{2} \mathrm{PO}_{4}$, $0.7 ; \mathrm{K}_{2} \mathrm{HPO}_{4}, 0.7 ; \mathrm{NH}_{4} \mathrm{Cl}, 0.5 ; \mathrm{MgSO}_{4} .7 \mathrm{H}_{2} \mathrm{O}, 0.1 ; \mathrm{NaCl}$, 1.0; sodium ascorbate, 1.0; glucose, 2.0; peptone, 2.0. One gram of the permafrost sample was suspended in $10 \mathrm{ml}$ medium in Hungate roll tubes under anaerobic conditions and incubated at $6{ }^{\circ} \mathrm{C}$ for 3 months up to a turbidity $\left(\mathrm{OD}_{600}\right)$ of 0.6. After incubation, the enrichment culture was transferred into a sterile medium of the same composition and serial tenfold dilutions were made. Aliquot from the highest dilutions were plated on Petri dishes of the same medium solidified with $20 \mathrm{~g}_{\text {agar }} \mathrm{l}^{-1}$. The dishes were incubated in Oxoid anaerostats at $6{ }^{\circ} \mathrm{C}$ for 1 month. As a result of serial transfers of single colonies from solid to liquid medium, a pure culture of a psychrotolerant anaerobic bacterium with a fermentative type of metabolism (designated strain $\mathrm{A} 121^{\mathrm{T}}$ ) was isolated. The pure culture of strain $\mathrm{A} 121^{\mathrm{T}}$ was maintained and cultivated in PY broth of the following composition ( $\mathrm{g}$ $1^{-1}$ ): peptone, 5.0; tryptone, 5.0; yeast extract, 10.0; salt solution, $10 \mathrm{ml}$. The salt solution contained $\left(\mathrm{g} \mathrm{l}^{-1}\right): \mathrm{CaCl}_{2}$, $0.2 ; \mathrm{MgSO}_{4} .7 \mathrm{H}_{2} \mathrm{O}, 0.48 ; \mathrm{K}_{2} \mathrm{HPO}_{4}, 1.0 ; \mathrm{KH}_{2} \mathrm{PO}_{4}, 1.0$; $\mathrm{NaHCO}_{3}, 10.0 ; \mathrm{NaCl}, 2.0$.

Motility and cell morphology were examined using an Axiostar Plus phase-contrast light microscope (Carl Zeiss) at a magnification of $\times 100$; cells for analysis were grown for $24-48 \mathrm{~h}$ in PY broth at $15{ }^{\circ} \mathrm{C}$. Electron microscopy of ultrathin sections for examination of cellular and spore ultrastructure was performed as described previously (Shcherbakova et al., 2005). Growth rates were measured by $\mathrm{OD}_{600}$ using a Specol-221 spectrophotometer (Carl Zeiss); the incubation time was $48-72 \mathrm{~h}$. The effect of $\mathrm{pH}$ on growth was measured at the optimal growth temperature of $15{ }^{\circ} \mathrm{C}$; the $\mathrm{pH}$ of basal PY medium was adjusted by adding sterile $6 \mathrm{M}$ solutions of $\mathrm{HCl}$ or $\mathrm{NaOH}$. The influence of $\mathrm{NaCl}$ concentration on growth was examined at the optimal growth temperature $\left(15{ }^{\circ} \mathrm{C}\right)$ and $\mathrm{pH}$ $(\mathrm{pH}$ 6.5-7.2) in basal medium containing $0,0.5,1.0,2.0$, $5.0,10.0$ or $15.0 \%(\mathrm{w} / \mathrm{v}) \mathrm{NaCl}$. The viability of cells was tested by heating $24 \mathrm{~h}$ liquid cultures of strain $\mathrm{A} 121^{\mathrm{T}}$ at $37{ }^{\circ} \mathrm{C}$ (for $24 \mathrm{~h}$ ), at $50,60,70$ and $80{ }^{\circ} \mathrm{C}$ (for $10 \mathrm{~min}$ in a water bath) and by placing a culture in a freezer at $-40{ }^{\circ} \mathrm{C}$ for 2 months with subsequent thawing by increasing the temperature up to $5{ }^{\circ} \mathrm{C}$ over $30 \mathrm{~min}$. After each treatment, the cultures were observed by microscopy and then transferred to fresh medium and incubated under optimal conditions.

Phenotypic tests to determine standard taxonomic characteristics such as Gram-staining and the presence of oxidase and catalase were performed following standard protocols (Gerhardt et al., 1994). The substrate utilization pattern of strain $\mathrm{A} 121^{\mathrm{T}}$ was examined in mineral medium with $3 \mathrm{~g}$ yeast extract $1^{-1}$ by adding sterile solutions of substrates with end concentrations of $3 \mathrm{~g} \mathrm{l}^{-1}$. The cultures were incubated for 3 days; growth was determined by $\mathrm{OD}_{600}$ and confirmed by two additional transfers. For the detection of nitratereducing and sulfate-reducing activities, the strain was cultivated in basal PY medium at the optimal growth temperature with addition of sterile solutions of $\mathrm{NaNO}_{3}$, $\mathrm{Na}_{2} \mathrm{~S}_{2} \mathrm{O}_{3}, \mathrm{Na}_{2} \mathrm{SO}_{3}$ and $\mathrm{Na}_{2} \mathrm{SO}_{4}$ (final concentration of each compound $2 \mathrm{~g} \mathrm{l}^{-1}$ ). Fermentation products (alcohols and fatty acids) formed in PY broth were analysed and quantified as described previously (Shcherbakova et al., 2005). $\mathrm{H}_{2}$ and $\mathrm{CO}_{2}$ were analysed by GC according to Shtarkman et al. (1995). Lactate was determined with lactate dehydrogenase by a colorimetric method (Hohorst, 1970). Analysis of the cell-wall peptidoglycan was performed as described by Schleifer \& Kandler (1972). The fatty acid pattern of strain $\mathrm{A} 121^{\mathrm{T}}$ was identified as described previously (Shcherbakova et al., 2005).

The 16S rRNA gene was amplified by PCR using a Perkin Elmer model 2400 DNA thermal cycler. The gene was amplified in a $50 \mu \mathrm{l}$ reaction mixture containing $2 \mu \mathrm{l}$ (approx. $0.3 \mathrm{ng})$ template DNA, $1 \mu \mathrm{l}(10 \mathrm{pmol})$ of each primer (Helicon) and a PCR kit (Fermentas) containing $5 \mu \mathrm{l}$ PCR buffer with $25 \mathrm{mM} \mathrm{MgCl}_{2}, 2 \mu \mathrm{l}$ dNTP mixture $(0.2 \mathrm{mM})$ and $1 \mu \mathrm{l}$ Taq polymerase $\left(5 \mathrm{U}^{-1} \mathrm{l}^{-1}\right)$. The universal prokaryotic primers 27F (5'-AGAGTTTGATCCTGGCTCAG) and 1492r (5'-TACGGYTACCTTGTTACGATT) were used. The PCR conditions were $94{ }^{\circ} \mathrm{C}$ for $10 \mathrm{~min}$ for primary denaturation, followed by 30 cycles of $94{ }^{\circ} \mathrm{C}$ for $30 \mathrm{~s}$ (denaturation), $55{ }^{\circ} \mathrm{C}$ for $30 \mathrm{~s}$ (annealing) and $72{ }^{\circ} \mathrm{C}$ for $120 \mathrm{~s}$ (chain extension) and a final $5 \mathrm{~min}$ chain-extension step at $72{ }^{\circ} \mathrm{C}$. The obtained PCR product was purified by using the Wizard PCR Preps DNA purification system (Promega) and sequenced. Sequencing reactions were performed using a CEQ dye terminator cycle sequencing kit (Beckman Coulter) and a CEQ2000 XL automatic DNA sequencer (Beckman Coulter), according to the protocols provided by the manufacturer. Reference sequences of the closest species were retrieved from GenBank (Benson et al., 1999) by using tools of the NCBI BLAST and the Ribosomal Database Project II (Maidak et al., 2001). Sequences were aligned and edited by using the sequence alignment editor BioEdit version 7.0.5.3 (Hall, 1999). The program TREECON W (Van de Peer \& De Wachter, 1994) was applied for construction of a phylogenetic tree using the neighbour-joining method (Saitou \& Nei, 1987) and Jukes-Cantor distance estimation (Jukes \& Cantor, 1969); the topology of the phylogenetic 
tree was evaluated by using the bootstrap resampling method of Felsenstein (1985) based on 1000 replicates. The branching obtained was confirmed by high values of branching probability. The DNA G+C content was assessed by thermal denaturation of DNA using a Pye Unicam SP1800 spectrophotometer; DNA for this analysis was extracted by the method of Marmur (1961). DNADNA reassociation analysis was performed as described by
De Ley et al. (1970); genomic DNA for this analysis was extracted by the method of Sambrook et al. (1989).

Differential genotypic and phenotypic characteristics of strain $\mathrm{A} 121^{\mathrm{T}}$ are given in the species description and in Table 1, in comparison with phylogenetically close Clostridium species. Phenotypically, the isolate matched the description of the genus Clostridium perfectly: cells of

\section{Table 1. Differential characteristics of strain $A 121^{\top}$ and phylogenetically close Clostridium species}

Strains: 1, A121 ${ }^{\mathrm{T}} ; 2$, 'C. algoriphilum' DSM 16153; 3, C. bowmanii DSM $14206^{\mathrm{T}} ; 4$, C. frigoris DSM 14204 ${ }^{\mathrm{T}} ; 5$, C. lacusfrixellense DSM 14205 ${ }^{\mathrm{T}}$; 6, C. psychrophilum DSM $14207^{\mathrm{T}} ; 7$, C. estertheticum subsp. laramiense DSM $14864^{\mathrm{T}} ; 8$, C. estertheticum subsp. estertheticum DSM $8809^{\mathrm{T}}$. Data for reference strains were taken from Shcherbakova et al. (2005) ('C. algoriphilum' DSM 16153) and Spring et al. (2003) (remaining reference strains). All strains were positive for the utilization of glucose and fructose. Substrate utilization was determined by measuring the increase in $\mathrm{OD}_{600}$ : + , strong production of gas and acid; w, weak production; -, no significant gas or acid produced. ND, No data available.

\begin{tabular}{|c|c|c|c|c|c|c|c|c|}
\hline Characteristic & 1 & 2 & 3 & 4 & 5 & 6 & 7 & 8 \\
\hline Spore location $\dagger$ & ST & C & $\mathrm{T}-\mathrm{ST}$ & $\mathrm{T}$ & $\mathrm{T}-\mathrm{ST}$ & $\mathrm{T}-\mathrm{ST}$ & $\mathrm{ST}-\mathrm{T}$ & $\mathrm{ST}-\mathrm{C}$ \\
\hline pH optimum & $6.5-7.2$ & $6.5-7.2$ & $6.6-7.2$ & $6.8-7.2$ & $6.5-7.1$ & $6.5-7.0$ & 6.5 & $6.5-7.2$ \\
\hline \multicolumn{9}{|l|}{ Utilization of: } \\
\hline Arabinose & - & + & - & + & - & + & $+(-)^{a_{\ddagger}}$ & + \\
\hline Inositol & - & + & - & $\mathrm{w}$ & + & - & + & + \\
\hline Lactose & - & + & - & + & + & - & - & - \\
\hline Maltose & + & + & + & + & - & + & + & + \\
\hline Mannitol & - & + & - & - & + & - & + & + \\
\hline Mannose & - & + & + & + & - & + & + & + \\
\hline Sucrose & - & + & + & + & + & + & + & + \\
\hline Xylose & - & + & + & + & + & + & $+(-)^{a}$ & + \\
\hline Ribose & - & + & + & $\mathrm{w}$ & + & - & - & - \\
\hline Starch & + & - & - & + & + & - & + & $\mathrm{W}(+)^{b}$ \\
\hline Salicin & - & + & + & + & + & - & + & + \\
\hline Trehalose & + & + & + & + & + & + & - & - \\
\hline Xylan & - & + & ND & ND & ND & ND & ND & ND \\
\hline \multicolumn{9}{|l|}{ Hydrolysis of: } \\
\hline Starch & - & - & - & - & - & - & + & $\mathrm{w}(+)^{b}$ \\
\hline Gelatin & + & - & - & - & - & - & - & - \\
\hline Fermentation products $\S$ & $\begin{array}{c}\mathrm{A}, \mathrm{B}, \mathrm{v} \\
\mathrm{f}, 2\end{array}$ & $\begin{array}{c}\mathrm{B}, \mathrm{L}, \mathrm{a} \\
\quad \mathrm{f}, 2\end{array}$ & $\begin{array}{r}\text { B, A, f, } \\
2,1,4\end{array}$ & $\begin{array}{c}\mathrm{B}, \mathrm{f}, \mathrm{l} \\
\mathrm{a}, 2\end{array}$ & $\begin{array}{c}\mathrm{B}, \mathrm{F}, \mathrm{a}, \\
1,2\end{array}$ & $\begin{array}{r}\mathrm{L}, 2, \\
4, \mathrm{~b}\end{array}$ & $\begin{array}{r}\mathrm{B}, 4,1 \\
\mathrm{a}, \mathrm{f}, 2\end{array}$ & $\begin{array}{r}\mathrm{B}, \mathrm{A}, \mathrm{f} \\
1,4,2\end{array}$ \\
\hline
\end{tabular}

${ }^{\star} \mathrm{E}$, Ellipsoidal; s, spherical.

$\dagger \mathrm{C}$, Central; ST, subterminal; T, terminal.

¥Data in parentheses differ from results obtained by Spring et al. (2003) and were taken from: $a$, Kalchayanand et al. (1993); $b$, Collins et al. (1992). \$a, Acetic acid; b, butyric acid; f, formic acid; v, valeric acid; l, lactic acid; 2, ethanol; 4, butanol. The sequence of products listed reflects decreasing concentration; capitals indicate concentrations above $10 \mathrm{mM}$. Fermentation products produced only in small amounts $(<1 \mathrm{mM})$ were not considered. 
the strain were Gram-positive rods that formed spherical endospores (Fig. 1), and the strain was obligately anaerobic and unable to carry out dissimilatory reduction of sulfate. According to the classification of Morita (1975), the strain was psychrotolerant: growth occurred at temperatures of
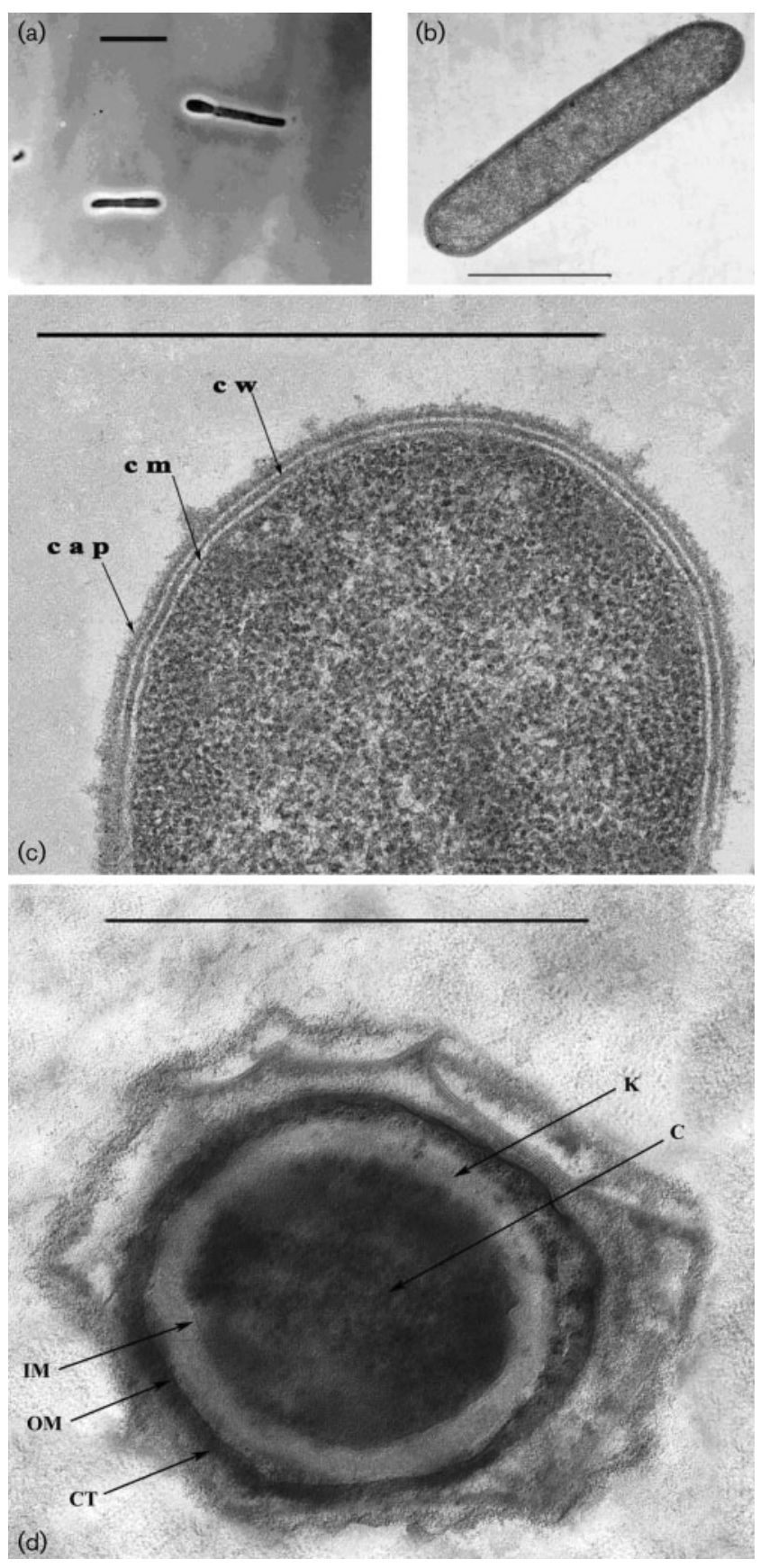

Fig. 1. Micrographs of cells of strain $A 121^{\top}$. (a) Phase-contrast micrograph (bar, $10 \mu \mathrm{m})$; (b, c), ultrathin sections of actively growing cells (bars, $1 \mu \mathrm{m}$ ); (d) ultrathin section of spore (bar, $1 \mu \mathrm{m}) . \mathrm{cw}$, Cell wall; cm, cytoplasmic membrane; cap, capsule, C, core; K, cortex; IM, inner membrane; OM, outer membrane; CT, spore coat.
4-28 ${ }^{\circ} \mathrm{C}$ (optimum $15-20{ }^{\circ} \mathrm{C}$ ), but did not grow at $37{ }^{\circ} \mathrm{C}$. Very slow growth was observed at $-2{ }^{\circ} \mathrm{C}$ after 2 months of incubation. The strain grew at $\mathrm{pH}$ 6.0-8.0 (optimum $\mathrm{pH}$ 6.5-7.2) and in $\mathrm{NaCl}$ concentrations between 0 and $12-14 \%(\mathrm{w} / \mathrm{v})$ (optimum $0-2.0 \%)$. The doubling time of strain $\mathrm{A}_{12} 1^{\mathrm{T}}$ as defined by doubling of $\mathrm{OD}_{600}$ in the exponential phase of growth was $12.7 \mathrm{~h}$ under optimal growth conditions. Plots demonstrating the influence of temperature and $\mathrm{NaCl}$ concentration on growth of strain A $121^{\mathrm{T}}$ are available as Supplementary Fig. S1 in IJSEM Online. Cells of the strain did not survive heating at $37{ }^{\circ} \mathrm{C}$ or above, but survived freezing at $-40{ }^{\circ} \mathrm{C}$ for 2 months; spore formation was not observed after heating, but single spores were found after freeze-thaw treatment. These features of cell viability and spore formation seem to correspond to the nature of the isolation source and the psychrotolerant temperature pattern of the isolate. Strain $\mathrm{A} 121^{\mathrm{T}}$ did not exhibit any nitrate-reducing or sulfatereducing activity. In comparison with related clostridial species, the isolate utilized a much narrower range of carbohydrates: only glucose, fructose, maltose, trehalose and starch supported growth. In contrast to related clostridial species, strain $\mathrm{A} 121^{\mathrm{T}}$ hydrolysed gelatin. The major fermentation products after 10 days of incubation were acetate $(33.3 \mathrm{mM})$, butyrate $(11.3 \mathrm{mM})$, isobutyrate $(6.3 \mathrm{mM})$ and valerate $(3.8 \mathrm{mM})$. Additionally, small amounts of formate and ethanol were produced $(<1 \mathrm{mM})$; lactate was not detected. $\mathrm{H}_{2}(10 \%)$ and $\mathrm{CO}_{2}$ $(12 \%)$ accumulated in the gas phase after incubation. The fatty acid patterns of strain $\mathrm{A} 121^{\mathrm{T}}$ and related strains are available in Supplementary Table S1. Comparison with patterns of related members of the genus Clostridium revealed certain common features: domination of monounsaturated omega-7-cis-hexadecene acid $\left(\mathrm{C}_{16: 1}\right.$ cis 9 ; $18.8 \%)$ and hexadecene aldehyde $\left(\mathrm{C}_{16: 1}\right.$ cis 9 DMA; $22 \%)$ and unsaturated palmitic acid $\left(\mathrm{C}_{16: 0} ; 15 \%\right)$ and myristic acid $\left(\mathrm{C}_{14: 0} ; 10.4 \%\right)$. The only exception is ' $C$. algoriphilum' DSM 16153, which demonstrated somewhat different features (Supplementary Table S1).

Phylogenetic analysis of the 16S rRNA gene sequence (1454 nt) of strain $\mathrm{A} 121^{\mathrm{T}}$ (Fig. 2 and Supplementary Fig. S2) shows that the isolate is closely related to the group of psychrotolerant and psychrophilic species that form an isolated branch within cluster I of the genus Clostridium; $C$. bowmanii DSM $14206^{\mathrm{T}}$ was the closest match, with a sequence identity of $98.5 \%$. The $16 \mathrm{~S}$ rRNA gene sequence identity between the isolate and strains of related species was $98-98.5 \%$ (Table 1) with the exception of $C$. psychrophilum A-1/C-an $/ \mathrm{I}^{\mathrm{T}}$, which showed lower identity $(96.4 \%)$; similarity with more distant species, not included in this branch, was less than $96 \%$. These sequence identity data agree with the range of $92-99 \%$ that was suggested as a range of similarity for members of cluster I, or Clostridium sensu stricto (Wiegel et al., 2006). The DNA $\mathrm{G}+\mathrm{C}$ content of strain $\mathrm{A} 121^{\mathrm{T}}$ (31.5 mol\%) was very close to reported values for related clostridial species (Table 1); however, DNA-DNA reassociation between strain $\mathrm{A} 121^{\mathrm{T}}$ 
002

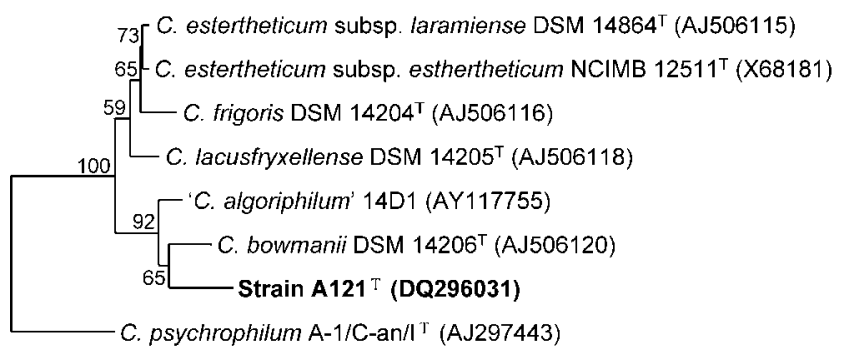

Fig. 2. Position of strain $A 121^{\top}$ among closely related species of cluster I of the genus Clostridium, based on 16S rRNA gene sequence phylogenetic analysis. GenBank accession numbers are shown in parentheses. The tree was built with the neighbourjoining method (Saitou \& Nei, 1987) by using Jukes-Cantor distance estimation (Jukes \& Cantor, 1969). Bootstrap percentages (from 1000 bootstrap resamplings for each node) are shown at branching points. Bar, 0.02 estimated substitutions per nucleotide position. A version of this tree incorporating an extended selection of reference sequences is available as Supplementary Fig. S2.

and strains of these species was much lower than the conventional $70 \%$ threshold (Wayne et al., 1987; Stackebrandt \& Goebel, 1994), thus indicating that the isolate represents a distinct species (Table 1).

On the basis of the data presented, isolate $\mathrm{A} 121^{\mathrm{T}}$ should be classified as a member of a novel species of the genus Clostridium, for which the name Clostridium tagluense sp. nov. is proposed.

\section{Description of Clostridium tagluense sp. nov.}

Clostridium tagluense (tag.lu.en'se. N.L. neut. adj. tagluense after the Taglu gas-hydrate field in the Northwest Territories of Canada, the source of isolation of the type strain).

Cells are Gram-positive, motile rods with rounded ends $(1.0-1.2 \times 3-10 \mu \mathrm{m})$, occurring singly or in pairs. Endospores are spherical, located in a subterminal position. Colonies on PY agar are round, convex, creamcoloured and 1-2 $\mathrm{mm}$ in diameter. Obligate anaerobe; catalase- and oxidase-negative. Nitrate and sulfate are not reduced. The temperature optimum for growth is 15$20{ }^{\circ} \mathrm{C}$; the lower growth limit is $4{ }^{\circ} \mathrm{C}$ and the upper growth limit is $28{ }^{\circ} \mathrm{C}$. No growth at $37{ }^{\circ} \mathrm{C}$. Grows at pH 6.0-8.0 (optimum $\mathrm{pH}$ 6.5-7.2) and in $\mathrm{NaCl}$ concentrations between 0 and 12-14\% (w/v) (optimum 0-2.0\%). Under optimal conditions, the doubling time is $12.7 \mathrm{~h}$. Fermentable compounds include fumarate, malate, trypticase, betaine, choline, glucose, maltose, fructose, trehalose and starch. Xylose, xylan, arabinose, cellobiose, lactose, mannose, sucrose, ribose, raffinose, rhamnose, melibiose, melezitose, inositol, mannitol and salicin do not support growth. Gelatin is hydrolysed, but starch is not. Major fermentation products formed in PY broth are acetate, butyrate, valerate, $\mathrm{H}_{2}$ and $\mathrm{CO}_{2}$. The cell-wall peptidoglycan contains meso-diaminopimelic acid. Major cellular fatty acids are $\mathrm{C}_{16: 1}$ cis 9 DMA, $\mathrm{C}_{16: 1}$ cis $9, \mathrm{C}_{16: 0}$ and $\mathrm{C}_{14: 0}$. The DNA G $+\mathrm{C}$ content of the type strain is $31.5 \mathrm{~mol} \%$.

The type strain, A12 $1^{\mathrm{T}}\left(=\mathrm{VKM} B-2369^{\mathrm{T}}=\mathrm{DSM} 17763^{\mathrm{T}}\right)$, was isolated from a permafrost sample from the core of the borehole 92GSCTaglu in the Mackenzie Delta, Northwest Territories, Canada.

\section{Acknowledgements}

We are grateful to Dr Scott Dallimore and the Geological Survey of Canada for permafrost samples, Dr Stefan Spring (DSMZ) for providing strains for comparative studies and Dr Georgy Osipov for assistance with cell-wall fatty acid analysis. This study was supported by the Russian Foundation for Basic Research (projects 06-04-49011 and 08-05-00268).

\section{References}

Benson, D. A., Boguski, M. S., Lipman, D. J., Ostell, J., Oullette, B. F. F., Rapp, B. A. \& Wheeler, D. L. (1999). GenBank. Nucleic Acids Res 27, 12-17.

Broda, D. M., Lawson, P. A., Bell, R. G. \& Musgrave, D. R. (1999). Clostridium frigidicarnis sp. nov., a psychrotolerant bacterium associated with 'blown pack' spoilage of vacuum-packed meats. Int J Syst Bacteriol 49, 1539-1550.

Collins, M. D., Rodrigues, U. M., Dainty, R. H., Edwards, R. A. \& Roberts, T. A. (1992). Taxonomic studies on a psychrophilic Clostridium from vacuum-packed beef: description of Clostridium estertheticum sp. nov. FEMS Microbiol Lett 75, 235-240.

Collins, M. D., Lawson, P. A., Willems, A., Cordoba, J. J., FernandezGarayzabal, J., Garcia, P., Hippe, H. \& Farrow, J. A. E. (1994). The phylogeny of the genus Clostridium: proposal of five new genera and eleven new species combinations. Int J Syst Bacteriol 44, 812-826.

De Ley, J., Cattoir, H. \& Reynaerts, A. (1970). The quantitative measurement of DNA hybridization from renaturation rates. Eur $J$ Biochem 12, 133-142.

Felsenstein, J. (1985). Confidence limits on phylogenies: an approach using the bootstrap. Evolution 39, 783-791.

Garrity, G. M., Bell, J. A. \& Lilburn, T. G. (2004). Taxonomic outline of the prokaryotes. In Bergey's Manual of Systematic Bacteriology, 2nd edn, release 5.0. New York: Springer.

Gerhardt, P., Murray, R. G. E., Wood, W. A. \& Krieg, N. R. (editors) (1994). Methods for General and Molecular Bacteriology. Washington, DC: American Society for Microbiology.

Gilichinsky, D., Rivkina, E., Bakermans, C., Shcherbakova, V., Petrovskaya, L., Ozerskaya, S., Ivanushkina, N., Kochkina, G., Laurinavichuis, K. \& other authors (2005). Biodiversity of cryopegs in permafrost. FEMS Microbiol Ecol 53, 117-128.

Hall, T. A. (1999). BioEdit: a user-friendly biological sequence alignment editor and analysis program for Windows 95/98/NT. Nucleic Acids Symp Ser 41, 95-98.

Hippe, H., Andreesen, J. R. \& Gottschalk, G. (1992). The genus Clostridium - nonmedical. In The Prokaryotes, 2nd edn, pp. 18001866. Edited by A. Balows, H. G. Trüper, M. Dworkin, W. Harder \& K. H. Schleifer. New York: Springer.

Hohorst, H. J. (1970). ( + )-Lactate. In Methods of Enzymatic Analysis, vol. 2, p. 1425. Weinhein: Verlag Chemie. 
Hungate, R. E. (1969). A roll tube method for cultivation of strict anaerobes. Methods Microbiol 3B, 117-132.

Jukes, T. H. \& Cantor, C. R. (1969). Evolution of protein molecules. In Mammalian Protein Metabolism, vol. 3, pp. 21-132. Edited by H. N. Munro. New York: Academic Press.

Kalchayanand, N., Ray, B. \& Field, R. A. (1993). Characteristics of psychrotrophic Clostridium laramie causing spoilage of vacuumpackaged refrigerated fresh and roasted beef. J Food Prot 56, 13-17.

Lawson, P., Dainty, R. H., Kristiansen, N., Berg, J. \& Collins, M. D. (1994). Characterization of a psychrotrophic Clostridium causing spoilage in vacuum-packed cooked pork: description of Clostridium algidicarnis sp. nov. Lett Appl Microbiol 19, 153-157.

Maidak, B. L., Cole, J. R., Lilburn, T. G., Parker, C. T., Jr, Saxman, P. R., Farris, R. J., Garrity, G. M., Olsen, G. J., Schmidt, T. M. \& Tiedje, J. M. (2001). The RDP-II (Ribosomal Database Project). Nucleic Acids Res 29, 173-174.

Marmur, J. (1961). A procedure for the isolation of deoxyribonucleic acid from microorganisms. J Mol Biol 3, 208-218.

Morita, R. Y. (1975). Psychrophilic bacteria. Bacteriol Rev 39, 144-167.

Mountfort, D. O., Rainey, F. A., Burghardt, J., Kaspar, H. F. \& Stackebrandt, E. (1997). Clostridium vincentii sp. nov., a new obligately anaerobic, saccharolytic, psychrophilic bacterium isolated from low-salinity pond sediment of the McMurdo Ice Shelf, Antarctica. Arch Microbiol 167, 54-60.

Saitou, N. \& Nei, M. (1987). The neighbor-joining method: a new method for reconstructing phylogenetic trees. Mol Biol Evol 4, 406-425.

Sambrook, J., Fritsch, E. F. \& Maniatis, T. (1989). Molecular Cloning: a Laboratory Manual, 2nd edn. Cold Spring Harbor, NY: Cold Spring Harbor Laboratory.

Schleifer, K. H. \& Kandler, O. (1972). Peptidoglycan types of bacterial cell walls and their taxonomic implications. Bacteriol Rev 36, 407-477.

Shcherbakova, V. A., Chuvilskaya, N. A., Rivkina, E. M., Pecheritsyna, S. A., Laurinavichuis, K. S., Suzina, N. E., Osipov,
G. A., Lysenko, A. M., Gilichinsky, D. A. \& Akimenko, V. K. (2005). Novel psychrophilic aerobic spore-forming bacterium from the overcooled water brine in permafrost: description Clostridium algoriphilum sp. nov. Extremophiles 9, 239-246.

Shtarkman, N. B., Obraztsova, A. Ya., Laurinavichuis, K. S., Galushko, A. S. \& Akimenko, V. K. (1995). Enhanced conversion of (meth)acrylic acids to methane by association of specific anaerobic microflora and granulated sludge. Microbiology (English translation of Mikrobiologiia) 64, 270-274.

Spring, S., Merkhoffer, B., Weiss, N., Kroppenstedt, R. M., Hippe, H. \& Stackebrandt, E. (2003). Characterization of novel psychrophilic clostridia from an Antarctic microbial mat: description of Clostridium frigoris sp. nov., Clostridium lacusfryxellense sp. nov., Clostridium bowmanii sp. nov. and Clostridium psychrophilum sp. nov. and reclassification of Clostridium laramiense as Clostridium estertheticum subsp. laramiense subsp. nov. Int J Syst Evol Microbiol 53, 1019-1029.

Stackebrandt, E. \& Goebel, B. M. (1994). Taxonomic note: a place for DNA-DNA reassociation and 16S rRNA sequence analysis in the present species definition in bacteriology. Int J Syst Bacteriol 44, 846849.

Van de Peer, Y. \& De Wachter, R. (1994). TREECON for Windows: a software package for the construction and drawing of evolutionary trees for the Microsoft Windows environment. Comput Appl Biosci 10, 569-570.

Wayne, L. G., Brenner, D. J., Colwell, R. R., Grimont, P. A. D., Kandler, O., Krichevsky, M. I., Moore, L. H., Moore, W. E. C., Murray, R. G. E. \& other authors (1987). International Committee on Systematic Bacteriology. Report of the ad hoc committee on reconciliation of approaches to bacterial systematics. Int J Syst Bacteriol 37, 463-464.

Wiegel, J., Tanner, R. \& Rainey, F. (2006). An introduction to the family Clostridiaceae. In The Prokaryotes: a Handbook on the Biology of Bacteria, 3rd edn, pp. 654-678. Edited by M. Dworkin, S. Falkow, E. Rosenberg, K. H. Schleifer \& E. Stackebrandt. New York: Springer. 